\title{
Bacterial ecology of tilapia fresh fillets and some factors that can influence their microbial quality
}

\author{
Ecologia bacteriana de filés frescos de tilápia e de pontos \\ capazes de influenciar a sua qualidade microbiológica
}

\begin{abstract}
Cleube Andrade BOARI ${ }^{1 *}$, Gisele Inocêncio PEREIRA ${ }^{1}$, Carolina VALERIANO ${ }^{1}$, Belami Cássia SILVA ${ }^{1}$, Vinicíus Mendes de MORAIS ${ }^{1}$, Henrique Cesár Pereira FIGUEIREDO ${ }^{1}$, Roberta Hilsdor PICCOLI ${ }^{1}$
\end{abstract}

\begin{abstract}
The purpose of research was to investigate the bacterial ecology of tilapia (Oreochromis niloticus) fresh fillets and some factors that can influence its microbial quality. Samples of fish cultivation water $(n=20)$, tilapia tegument and gut $(n=20)$ and fresh fillets $(n=20)$ were collected in an experimental tilapia aquaculture located in the city of Lavras, Minas Gerais, Brazil. Staphylococcus spp., Aeromonas spp., Enterococcus spp. and Enterobacteriaceae were quantified using selective plating. For the enumeration of Pseudomonas spp., the most probable number technique (MPN) was utilized. Bacterial colonies $(\mathrm{n}=198)$ were identified by Gram strain and biochemical tests. Aeromonas spp., Pseudomonas spp., Enterococcus spp. and Enterobacteriaceae were found in the cultivation water (water from a fishpond cultivation), tegument, gut, and fresh fillets. Staphylococcus spp. was not isolated in the cultivation water. Salmonella spp. was not detected. The count variable of 10 to $10^{3} \mathrm{CFU}$ or MPN.(g or $\mathrm{mL})^{-1}$. Associated to freshwater tilapia fillet processing, there is a large variety of microorganisms related to foodborne illnesses and fish products deterioration.

Keywords: microbiology; aquaculture; tilapia; fillets; quality.
\end{abstract}

\section{Resumo}

A presente pesquisa foi conduzida com o objetivo de se investigar a ecologia microbiana de filés frescos de tilápia (Oreochromis niloticus) e de pontos capazes de influenciar em sua qualidade microbiológica. Para sua condução, amostras de água de cultivo ( $\mathrm{n}=20$ ), tegumento e trato gastrintestinal $(n=20)$ e filés frescos $(n=20)$ foram coletados em um sistema de produção aqüícola de água doce localizado em Lavras, Minas Gerais, Brasil. Staphylococcus spp., Aeromonas spp., Enterococcus spp., Enterobacteriaceae foram quantificados através de plaqueamento seletivo. Pseudomonas spp. foi enumerada através da técnica do número mais provável. Colônias $(\mathrm{n}=198)$ foram identificadas por coloração de Gram e testes bioquímicos. Aeromonas spp., Pseudomonas spp., Enterococcus spp. e Enterobacteriaceae foram detectados na água de cultivo, no tegumento e conteúdo do trato gastrintestinal e nos filés frescos. Staphylococcus spp. não foram isolados na água de cultivo. Salmonella spp. não foi isolada. As contagens microbianas variaram de 10 a $10^{3}$ UFC ou NMP.(g ou mL $)^{-1}$. Na cadeia de processamento de filés de tilápia, se encontra presente uma grande variedade de microrganismos associados a doenças veiculadas por alimentos e à deterioração de pescado e derivados.

Palavras-chave: microbiologia; aqüicultura; tilápia; filés; qualidade.

\section{Introduction}

Freshwater aquaculture represents an important source of animal protein to human nutrition. In this context, tilapia (Oreochromis niloticus) is the most cultivated freshwater fish species in Brazil due to its peculiar characteristics such as rusticity, resistance, productivity, and good sensorial properties of meat (MAREGONI, 2006; BOSCOLO et al., 2001).

Despite of all benefits, there is a considerable risk of microbial contamination in this activity and, consequently, in the finished products, which represents critical concerns to public health questions (ABABOUCH, 2006; ROTH; ROSENTHAL, 2006). This occurs because a large variety of pathogenic and putative bacteria can be introduced into different stages of the processing without proper control affecting directly the sensorial quality, safety, and the shelf life of fishery products (KOLODZIEJSKA et al., 2002). Foodborne diseases transmitted by many of these products may include some of those described for poultry and meats, as salmonellosis as well as diseases caused by aquatic microorganisms, particularly the Vibrionaceae (MOLINS, MOTARJEMI; KÄFERSTEIN, 2001).

Although there is a wide variation in the bacterial flora around the world due to geographic peculiarities, some genus are specially linked to aquaculture systems such as Aeromonas spp., Micrococcus spp., Staphylococcus spp., Bacillus spp., Pseudomonas spp., Plesiomonas spp., Moraxellaceae and Enterobacteriaceae (DASKALOV, 2006; NEDOHULA; WESTHOFF, 1997; SOUSA, 1996; BURRAS, 1993). Other important genus such as Listeria spp. have also been isolated from aquaculture products (JALLEWAR et al., 2007; DESTRO, 2000). 
It is necessary to identify the potential points of contamination in aquaculture and the prevalence of microbial species in each of them as the way to consider efficient strategies to avoid the dissemination of microorganisms in the food processing chain and to improve the quality and safety of the end products (SUMNER; ROSS, 2002).

Considering the need to provide more data about fish products microbiology, the purpose of this research was to investigate the bacterial ecology of tilapia (Oreochromis niloticus) fresh fillets and factors that can influence the microbial quality.

\section{Materials and methods}

\subsection{Samples}

Samples of water from a fishpond cultivation (20), fish tegument, gut (20), and fresh fillets (20) were collected in an experimental freshwater tilapia aquaculture located in the city of Lavras, Minas Gerais, Brazil, during the winter. The average water temperature was $20^{\circ} \mathrm{C}$.

\subsection{Microbiological analyzes}

\section{Staphylococcus spp.}

Staphylococcus spp. were enumerated and isolated by plating on Baird-Parker Agar (Biolife, Milano, Italy) and incubated at $37{ }^{\circ} \mathrm{C}$ for 48 hours. The colonies were subjected to Gram stain and biochemical tests (API Staphy, BioMérieux, France) (FDA, 2001; HOLT, 1994; MAC FADDIN, 1980).

\section{Aeromonas spp.}

Aeromonas spp. were enumerated and isolated by plating on Dextrin-Ampicilin Agar (ampicilin $10 \mathrm{mg} . \mathrm{L}^{-1}$ ) and incubated at $30{ }^{\circ} \mathrm{C}$ for 48 hours. Colonies were subjected to test of motile, Gram stain and biochemical tests of cytochrome oxidase, D-glucose fermentation, arginine dihydrolase, and ornithine decarboxylase, ONPG, $\mathrm{H}_{2} \mathrm{~S}$ from cysteine, acetoin from glucose, gas from glucose, L-arabinose utilization and fermentation of salicin (FDA, 2001; HOLT, 1994; MAC FADDIN, 1980).

\section{Pseudomonas spp.}

Pseudomonas spp. were quantified by the Most Probable Number technique (MPN) in Asparagine Enrichment Broth (Biolife, Milano, Italy) (presuntive test) and Acetamide Broth (confirmative test), both incubated at $30^{\circ} \mathrm{C}$ for 48 hours. Aliquots of positive Acetamide tubes were streaked onto Pseudomonas Selective Agar (Biolife, Milano, Italy) and incubated at $30^{\circ} \mathrm{C}$ for 48 hours. The colonies were subjected to Gram stain and biochemical tests (FDA, 2001; HOLT, 1994; MAC FADDIN, 1980).

\section{Enterococcus spp.}

Enterococcus spp. were enumerated and isolated by plating on KF Agar (Merck, Darmstadt, Germany) and incubated at $37{ }^{\circ} \mathrm{C}$ for 48 hours. The colonies were subjected to Gram stain and biochemical tests (API 20 Strep, BioMérieux, France) (FDA, 2001; HOLT, 1994; MAC FADDIN, 1980).

\section{Enterobacteriaceae}

Enterobacteriaceae species were enumerated and isolated by plating on Hecktoen Agar (Merck, Darmstadt, Germany) and incubated at $37^{\circ} \mathrm{C}$ for 48 hours. Colonies were subjected to Gram Stain and biochemical tests (API 20E, BioMérieux, France). The presence of Salmonella spp. was investigated by pre-enrichment in Buffered Peptone Water (Biolife, Milano, Italy), incubated at $37^{\circ} \mathrm{C}$ for 18 hours, and enrichment in Selenite Cystin Broth (Merck, Darmstadt, Germany) and Rappaport and Vassiliadiss Broth (Merck, Darmstadt, Germany), both incubated at $37^{\circ} \mathrm{C}$ for 24 hours. Selenite Cystine and Rappaport \& Vassiliadis cultures were streaked onto Rambach agar (Merck, Darmstadt, Germany) and Hecktoen agar (Merck, Darmstadt, Germany) and incubated at $37^{\circ} \mathrm{C}$ for 48 hours. Colonies suspected of being Salmonella spp. were transferred to Lysine Iron Agar (Merck, Darmstadt, Germany) and Triple Sugar Iron Agar (Merck, Darmstadt, Germany) and incubated at $37{ }^{\circ} \mathrm{C}$ for 48 hours (FDA, 2001; HOLT, 1994; MAC FADDIN, 1980).

\section{Results and discussions}

The counting in log of Colony-Forming Units (CFU) and Most Probable Number (MPN) of each genus are showed in Table 1. The species of microorganisms isolated and their frequency are showed in Table 2.

Although it is widely accepted that the initial microbial load of freshwater fish varies depending on the water conditions and temperature, most available literature on different freshwater fish species (tilapia, striped bass, rainbow trout, silver perch) report bacterial counts of $10^{2}-10^{6} \mathrm{CFU} \cdot \mathrm{g}^{-1}$ (CHYTIRI et al., 2004). The counts of Staphylococcus spp., Aeromonas spp., Enterococcus spp. and Enterobacteriaceae found ranged of 10 to $10^{3} \log \mathrm{CFU}$. (g or $\left.\mathrm{mL}\right)^{-1}$.

The genus Staphylococcus is made up of 36 validated species which contain strains that are pathogenic, saprophytic, or used as starter cultures for the food industry (IRLINGER, 2007). In this research, Staphylococcus spp. was not found in water samples from fishpond cultivation. However, it was isolated in other samples. Staphylococcus sciuri was found in fish tegument, gut, and fresh fillets. According to Lencastre et al. (1999), Wu et al. (1998), and Kloss et al. (1997) the relevance of this species is related to its high capacity of colonization because it can inhabit several environments such as soil, water, and animal skin, and it has been considered an important carrier of antibiotic resistance genes. S. xylosus was the other predominant species in the fish tegument and gut. No works were found in the literature reviewed associating this species to foodborne illnesses. According to Irlinger (2007), this microorganism has been considered a non-pathogenic, skin and mucous membrane. commensal organism and has rarely been reported associated with infections. S. aureus and S. gallinarum were found in fresh fillets. S. saprophyticus was isolated from the tegument and gut of the fresh fillets.

Regarding the potential impact of the presence of S. aureus in fishery products on public health, Simon and Sanjeev (2007) studied the prevalence of enterotoxigenic $S$. aureus in samples of fresh and frozen fillets colleted in local markets and in a fish 
Table 1. Count, in log CFU.(g or mL) $)^{-1}$, of Aeromonas spp., Enterococcus spp., Staphylococcus spp., Enterobacteriaceae and the Most Probable Number to Pseudomonas spp., in log MPN.(g or mL)-1, in the water used for cultivation, fish tegument, gut, and fresh fillets.

\begin{tabular}{lccc}
\hline \multicolumn{1}{c}{ Genus } & Cultivation water & Tegument and gut & Fresh fillets \\
\hline Staphylococcus spp. & - & $2.4 \log$ CFU.mL & $1.45 \log \mathrm{CFU} \cdot \mathrm{mL}^{-1}$ \\
Aeromonas spp. & $2.18 \log$ CFU.mL & 2.1 & $\log \log \mathrm{CFU} \cdot \mathrm{mL}^{-1}$ \\
Pseudomonas spp. & $1.90 \log \mathrm{MPN} \cdot \mathrm{mL}^{-1}$ & $3.67 \log$ CFU.mL & $1.68 \log \mathrm{MPN}^{-1} \mathrm{~mL}^{-1}$ \\
Enterococcus spp. & $2.79 \log \log \mathrm{CFU} \cdot \mathrm{mL}^{-1}$ & $2.05 \log \mathrm{MPN} \cdot \mathrm{mL}^{-1}$ & $1.41 \log \mathrm{CFU} \cdot \mathrm{mL}^{-1}$ \\
Enterobacteriaceae & $2.31 \log \mathrm{CFU} \cdot \mathrm{mL}^{-1}$ & $2.48 \log \log \mathrm{CFU} \cdot \mathrm{mL}^{-1}$ & $1.39 \log \mathrm{CFU} \cdot \mathrm{mL}^{-1}$ \\
\hline
\end{tabular}

Table 2. Species of Staphylococcus spp., Aeromonas spp., Pseudomonas spp., Enterococcus spp. and Enterobacteriaceae isolated from the cultivation water, fish tegument, gut, and fresh fillets and their respective frequency.

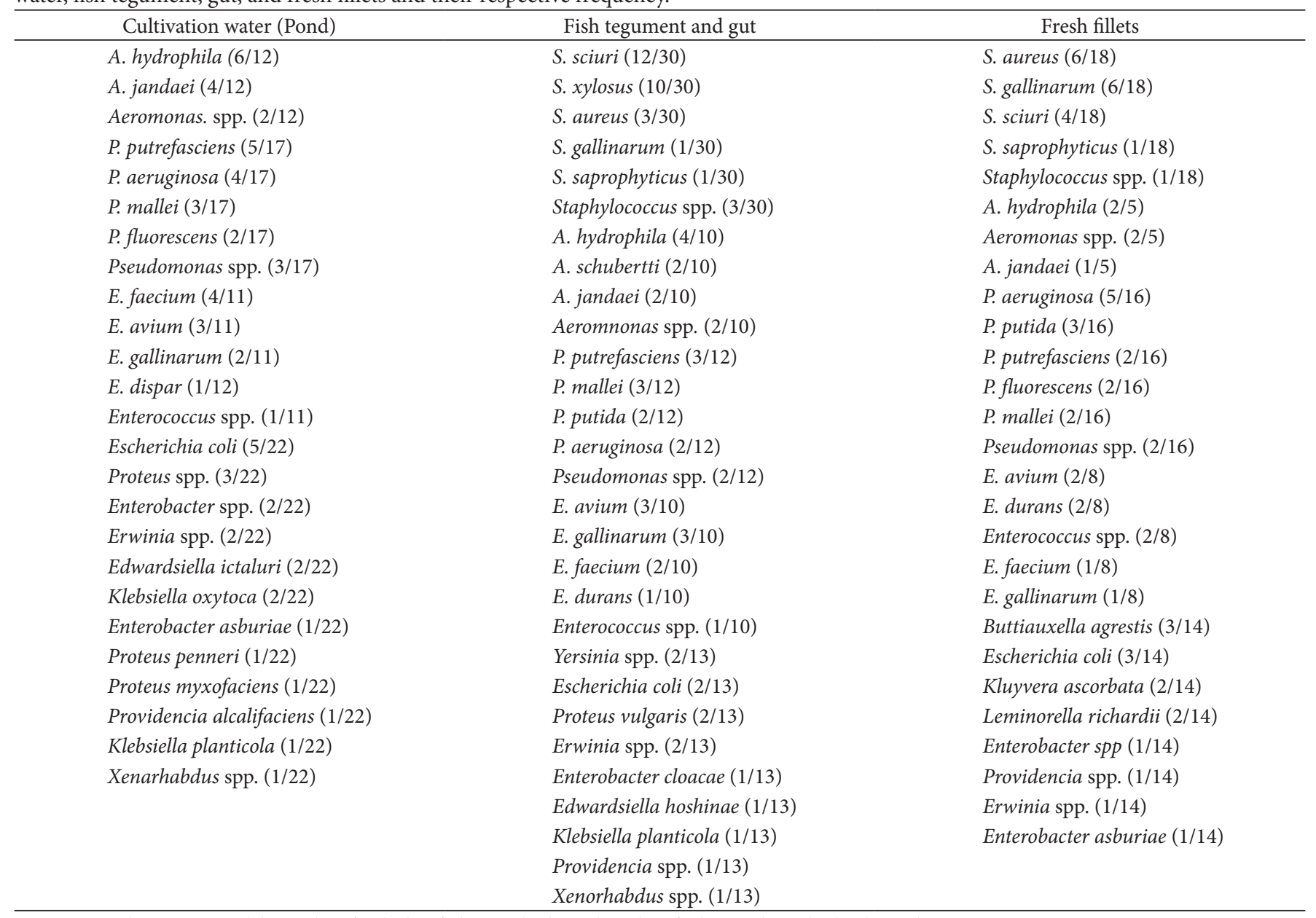

Note: in parenthesis is presented the number of each identified species by the total number of colonies subjected to biochemical tests.

processing plant in Cochin, India. They concluded that $10 \%$ (17 in 168) were positive to this pathogenic agent. According to these authors such presence can indicate unhygienic conditions during the processing because the product contamination could be the result of a combination of improper handling, improper storage, and cross contamination.

Pseudomonas spp. were isolated in all samples. The identified Pseudomonaceae were $P$. aeruginosa, $P$. putrefasciens, $P$. mallei, $P$.putida, and P. fluorescens. Although these species are not referred to as the cause of foodborne illnesses they are closely associated to food deterioration (TRYFINOPOULO et al., 2002). According to Tripathy et al. (2007) Pseudomonas spp. are frequently associated to fish and have been isolated from skin, gills, and intestine. Their load is explained by the population density in water. In an aquaculture, especially $P$. aeruginosa and P. fluorescens have been considered opportunistic pathogenic species (ALTINOK; KAVIS; CAPKIN, 2006). Aeromonas spp. was also detected in all samples, and A. hydrophila was the predominant species confirming its ubiquity in aquaculture (ALDERMAN; HASTINGS, 1998; NEDOLUHA; WESTTHOFF, 1997). The major population density was found in the tegument and gut $\left(3.67 \log \mathrm{CFU} \cdot \mathrm{g}^{-1}\right)$. In their study, Aly et al. (2008) found A. hydrophila in the stomach of diseased $O$. niloticus. Other identified species were A. Schubertti and A. Jandaei. As reported by Feldhusen (2000) Aeromonas spp. is largely found in aquatic environments and some strains are important fish pathogens in aquaculture while others have been implicated in foodborne diseases. Mesophilic Aeromonas spp. is increasingly recognized as human pathogens since they have been isolated from 
cases of gastrointestinal infection (VIVEKANANDHAN; HATHA; LAKSHMANAPERUMALSAMY, 2005; JANDA; ABBOTT, 1998). Both Pseudomonas spp. and Aeromonas spp. show high capacity to produce exoenzymes as lipases and proteases whose actions are associated to fish product deterioration (DASKALOV; 2006; TRYFINOPOULO et al., 2002; GRAM; DALGAARD, 2002; HUSS, 2000).

Enterococcus spp. was isolated from the water used for cultivation, fish tegument, gut, and fresh fillets. The identified species were E. gallinarum, E. avium, E. faecium, E. dispar, and E. durans. Several species of Enterobacteriaceae and Enterococcus spp. found in this research are potentially pathogenic to human.

Enterobacteriaceae members were found in the cultivation water, tegument, gut, and fresh fillets. The low count in fresh fillets (1.65 log CFU.g ${ }^{-1}$ ) was similar to the value found by Chytiri et al. (2004) of $1.65 \mathrm{log}$ CFU.g ${ }^{-1}$ in fresh trout fillet. Salmonella spp. was not isolated from any sampled points. Nevertheless, this specie may be found in aquacultures due to water pollution (BURRAS, 1993). The presence of Salmonella in water depends on many factors, for instance pollution from a nearby poultry farm (FELDHUSEN, 2000). Some Salmonella serovars may be found in fish feed and its ingredients as well as in food production facilities.

The bacterial ecology of fish products is connected to environmental factors such as water pollution, anthrop activities, fish feed quality, hygienic procedures of slaughter, handling, transport, commercialization, and storage conditions. In freshwater aquaculture, the microbial load in the water used for cultivation is closely connected to several factors such as bacterial ecology of supply water, environment (air and contamination by animal excrements), fish feed, soil, and water table (Figure 1). Hence, the microbial charge of fish gut and tegument depends on these factors too. Regarding the fresh fillets, the potential contamination in other steps of processing such as procedures of slaughter, handling, packing, and storage need to be considered. In conclusion, the microbial quality of this finished product is a somatory of the microbial load in many in steps of freshwater fishery products processing (ORBAN et al., 2006; ORBAN et al., 2005; GONZÁLEZ-FANDOS et al., 2004).

All aquaculture systems must be supervised when quality and safety of fish products are the focus. Knowledge about food microbiology, contamination sources, and control measures are of critical importance in order to prevent food deterioration and to avoid that hazards are passed down to consumers.

\section{Conclusion}

Aeromonas spp., Pseudomonas spp., Enterococcus spp. and Enterobacteriaceae were found in cultivation water, tegument, gut, and fresh fillets. Staphylococcus spp. was not found in the water from a fishpond cultivation. The count of microorganisms varied in the range of 10 to $10^{3} \mathrm{CFU}$ or MPN.(g or $\left.\mathrm{mL}\right)^{-1}$. Salmonella spp. was not detected.

Several species isolated are closely related to public health issues and food deterioration.

\section{Acknowledgements}

The authors are grateful for the financial support provided by the foundations CAPES (Brazilian research supporting foundation) and The National Council for Scientific and Technological Development (CNPq).

\section{References}

ABABOUCH, L. Assuring fish safety and quality in international fish trade. Marine Pollution Bulletin, v. 53, n. 10-12, p. 561-568, 2006.

ALDERMAN, D. J.; HASTINGS, T. S. Antibiotic use in aquaculture: development of antibiotic resistance-potential for consumer health
Freshwater aquaculture

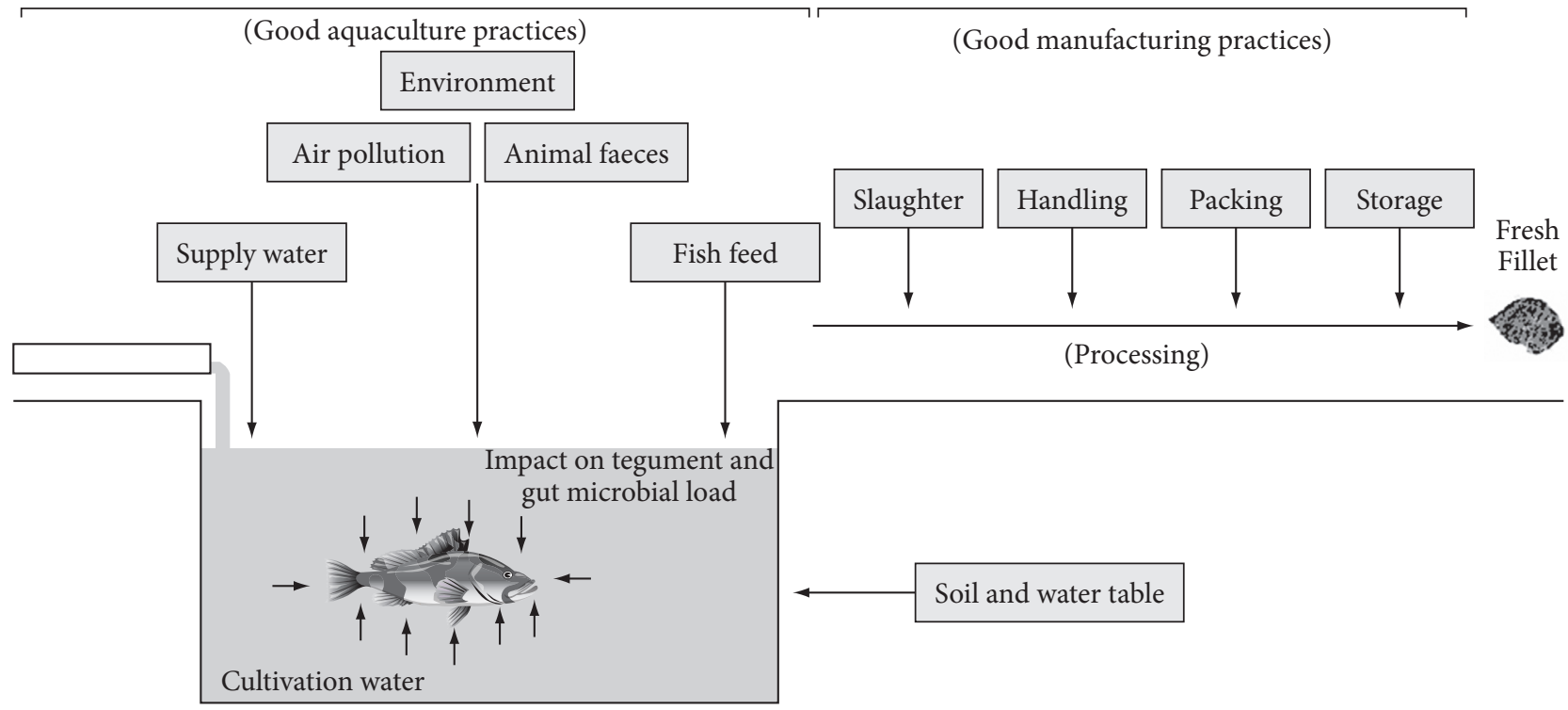

Figure 1. Factors and procedures that can influence the microbial quality of fresh fillet. 
risks. International Journal of Food Science and Technology, v. 33, n. 2, p. 139-155, 1998.

ALTINOK, I.; KAYIS, S.; CAPKIN, E. Pseudomonas putida infection in rainbow trout. Aquaculture, v. 261, n. 3, p. 850-855, 2006.

ALY, S. M. et al. Characterization of Some Bacteria Isolated from Oreochromis niloticus and their Potential Use as Probiotics. Aquaculture, v. 277, n. 1, p. 1-6, 2008.

BOSCOLO, W. R. et al. Desempenho e Características de Carcaça de Machos Revertidos de Tilápias do Nilo (Oreochromis niloticus), Linhagens Tailandesa e Comum, nas Fases Inicial e de Crescimento. Revista Brasileira de Zootecnia, v. 30, n. 5, p. 1391-1396, 2001.

BURRAS, N. Microbial safety of procedure from wastewaterfed aquaculture. In RVC Pullin, H. Rosenthal, J. L. MacLean. Envirmonment and aquaculture in developing countries. CLARM Conference. Proceedings... Manila, Philippines: International Centre for Living and Aquatic Resources, p. 285-295, 1993.

CHYTIRI, S. et al. Microbiological, chemical and sensory assessment of iced whole and filleted aquacultured rainbow trout. Food Microbiology, v. 21, n. 2, p. 157-165, 2004.

DASKALOV, H. The importance of Aeromonas hydrophila in food safety. Food Control, v. 17, n. 6, p. 474-483, 2006.

DESTRO, M. T. Incidence and significance of Listeria in fish and fish products from Latin America. International Journal of Food Microbiology, v. 62, n. 3, p. 191-196, 2000.

FDA. Bacteriological Analytical Manual on-line. USA: Center of Food Safety and Applied Nutrition, Food and Drug Administration, 2001.

FELDHUSEN, F. The role of seafood in bacterial foodborne diseases. Microbes and Infection, v. 2, n. 13, p. 1651-1660, 2000.

GONZÁLEZ-FANDOS, E. et al. Evaluation of the microbiological safety and sensory quality of rainbow trout (Oncorhynchus mykiss) processed by the sous vide method. Food Microbiology, v. 21, n. 2, p. 193-201, 2004.

GRAM, L.; DALGAARD, P. Fish spoilage bacteria - problems and solutions. Current Opinion in Biotechnology, v. 13, n.3, p. 262-266, 2002.

HOLT, J. G. Bergey's Manual of Determinative Bacteriology. 9 ed. Baltimore: Williams \& Wilkins, 1994.

HUSS, H. H.; REILLY, A.; EMBAREK, P. K. B. Prevention and control of hazards in seafood. Food Control, v. 11, n. 2, p. 149-156, 2000.

IRLINGER, F. Coagulase-negative staphylococci. International Journal of Food Microbiology, 2007. In Press.

JALLEAWAR, P. K. et al. Genotypic characterization of Listeria spp. isolated from fresh water fish. International Journal of Food Microbiology, v. 114, n. 1, p. 120-123, 2007.

JANDA, J. M.; ABBOTT, S. L. Evolving concepts regarding the genus Aeromonas: an expanding panorama of species, disease presentations and unanswered questions. Clinical Infectious Diseases, v. 27, n. 2, p. 332-344, 1998.

KLOOS, W. E. et al. Ribotype delineation and description of Staphylococcus sciuri subspecies and their potential as reservoirs of methicillin resistance and staphylolytic enzyme genes. International Journal of Systematic and Evolutionary Bacteriology, v. 47, n. 4, p. 313-323, 1997.

KOLODZIEJSKA, I. et al. The Microbial and Sensory Quality of Mackerel Hot Smoked in Mild Conditions. Lebensmittel-Wissenschaft und-Technologie, v. 35, n. 1, p. 87-92, 2002.
LENCASTRE, H. Detection of an archaic clone of Staphylococcus aureus with low level resistance to methicillin in a pediatric hospital in Portugal and in international samples: relics of a formerly widely disseminated strain?. Journal of Clinical Microbiology, v. 37, n. 6, p. 1913-1920, 1999.

LUNESTAD, B. T. et al. Salmonella in fish feed; occurrence and implications for fish and human health in Norway. Aquaculture, v. 265, n. 1-4, p. 1-8, 2007.

MAC FADDIN, J. F. 1980. Biochemical tests for identification of medical bacteria. 2 ed. London: Williams \& Williams, 1980.

MAREGONI, N. G. Produção de tilápia do Nilo Oreochromis niloticus (Linhagem Chitralada), cultivada em tanques-rede, sob diferentes densidades de estocagem. Revista Archivos de Zootecnia, v. 55, n. 210 , p. $127-138,2006$

MOLINS, R. A.; MOTARJEMI, Y.; KÄFERSTEIN, F. K. Irradiation: a critical control point in ensuring the microbiological safety of raw foods. Food Control, v. 12, n. 6, p. 347-356, 2001.

NEDOLUHA, P. C., WESTHOFF, D. 1997. Microbiology on striped bass grown in three aquaculture systems. Food Microbiology, v. 14, n. 3, p. 255-264, 1997.

ORBAN, E. et al. Nutritional quality and safety of European perch (Perca fluviatilis) from three lakes of Central Italy. Food Chemistry, 2005. In Press.

ORBAN, E. et al. Nutritional quality and safety of whitefish (Coregonus lavaretus) from Italian lakes. Journal of Food Composition and Analysis, v. 19, n. 6-7, p. 737-746, 2006.

ROTH, E.; ROSENTHAL, H. Fisheries and aquaculture industries involvement to control product health and quality safety to satisfy consumer-driven objectives on retail markets in Europe. Marine Pollution Bulletin, v. 53, n. 10-12, p. 599-605, 2006.

SIMON, S. S.; SANJEEV, S. Prevalence of enterotoxigenic Staphylococcus aureus in fishery products and fish processing factory workers. Food Control, v. 18, n. 12, p. 1565-1568, 2007.

SOUSA, J. A. et al. Health status of two salmonid aquaculture facilities in North Portugal: characterization of the bacterial and viral pathogens causing notificable diseases. Journal of Fish Disease, v. 19, n. 1, p. 83-89, 1996.

SUMNER, J.; ROSS, T. A semi-quantitative seafood safety risk assessment. International Journal of Food Microbiology, v. 77, n. 1-2, p. 55-59, 2002.

TRIPATHY, S. et al. Characterisation of Pseudomonas aeruginosa isolated from freshwater culture systems. Microbiological Research, v.162, n. 4, p. 391-396, 2007.

TRYFINOPOULO, P.; TSAKALIDOU, E.; NUCHAS, G. J. E. Characterization of Pseudomonas spp. Associated with spoilage of gilt-heat bream stored under various conditions. Applied and Environmental Microbiology, v. 68, n. 1, p. 65-72, 2002.

V I V E K A N A N D H A N, G.; HA THA, A. A. M.; LAKSHMANAPERUMALSAMY, P. Prevalence of Aeromonas hydrophila in fish and prawns from the seafood market of Coimbatore, South India. Food Microbiology, v. 22, n. 1, p. 133-137, 2005.

WU, S.; LENCASTRE, H.; TOMAS, A. Genetic organization of the mecA region in methicillin-susceptible and methicillin-resistant strains of Staphylococcus sciuri. Journal of Bacteriology, v. 180, n. 2, p. 236-242, 1998. 